\title{
Killing the Buddha: Ritualized Violence in Fight Club through the Lens of Rinzai Zen Buddhist Practice
}

\author{
Gregory Max Seton \\ Department of Religion, Dartmouth College, Hanover, NH 03755, USA; gregory.m.seton@dartmouth.edu
}

Received: 11 June 2018; Accepted: 27 June 2018; Published: 2 July 2018

\begin{abstract}
David Fincher may not be an expert in Buddhism. But his description of Fight Club - as reprising the figurative admonishment to "kill the buddha" by Lin-ji Yi-xuan (9th cent.), the founder of the Rinzai Zen Buddhist school—illuminates the way that Fincher's own directorial choices mirror the ritualized practices of Rinzai Zen aimed at producing insights into the imaginary and subjective nature of reality. Other articles have already looked from the perspective of film criticism at the many Buddhist (and non-Buddhist) diegetic elements in Fight Club's story, plot, and dialogue. In contrast, this article analyzes the non-diegetic elements of Fincher's mise-en-scène in Fight Club from the perspective of film theory in order to demonstrate the way they draw inspiration from certain Zen Buddhist pedagogical methods for breaking through to a "glimpse of awakening" $(k e n s h \bar{o})$. By reading David Fincher's directorial choices in light of Zen soteriology and the lived experience of Rinzai Zen informants, the article sheds light not only on the film's potentially revelatory effects on its viewers, but also on esoteric aspects of Rinzai Zen pedagogy as encapsulated in Lin-ji's "Three Mysterious Gates" and Hakuin's three essentials of practice.
\end{abstract}

Keywords: Buddhism; Zen; Rinzai Zen; film; film theory; violence; Fight Club; ritual

"I don't know if it's Buddhism, but there's the idea that on the path to enlightenment you have to kill your parents, your god, and your teacher."

—David Fincher, describing his film Fight Club (Smith [1999] 2014, p. 60)

David Fincher may not be an expert in Buddhism, but his description of "the defining cult movie of our time" (New York Times, Dennis Lim, 9 November 2006)—which reprises the figurative admonishment to "kill the buddha" by Lin-ji Yi-xuan (9th cent.), the founder of the Rinzai Zen Buddhist school-illuminates the way that Fincher's own directorial choices mirror the ritualized practices of Rinzai Zen aimed at producing insights into the imaginary and subjective nature of reality. ${ }^{1}$ Other articles (Fielding 2008, pp. 474-87; Reed 2007; Green 2014) have already looked from the perspective of film criticism at the many Buddhist (and non-Buddhist) diegetic elements in Fight Club's story, plot, and dialogue. In contrast, this article analyzes the non-diegetic elements of Fincher's mise-en-scène in Fight Club from the perspective of film theory in order to demonstrate the way they parallel Zen Buddhist pedagogical methods for breaking through to a "glimpse of awakening" (kenshō). ${ }^{2}$ By reading David Fincher's directorial choices in light of Zen soteriology and the lived experience of Rinzai Zen

1 In contemporary Japanese Buddhism, one finds two schools of Zen, namely Rinzai and Sōtō, who advocate different pedagogical approaches. Even though their interpretations of Zen may overlap in some regards, this article refers only to the Rinzai school and uses the more general term "Zen" exclusively to refer to the Rinzai interpretation.

2 For more on the difference between 'film criticism' and 'film theory,' see, e.g., (Elsaesser and Hagener 2010, p. 31-38), or (Braudy and Cohen 2004). 
informants, I hope to shed light not only on the film's potentially revelatory effects on its viewers, but also on certain esoteric aspects of Rinzai Zen pedagogy. ${ }^{3}$

In order to highlight Fight Club's salient, non-diegetic elements, this article is divided into three sections corresponding to Lin-ji's "Three Mysterious Gates" that encapsulate Rinzai Zen pedagogy (Buswell 1986, pp. 223-26). The first section sketches out the soteriological framework of Rinzai Zen Buddhism and the way that David Fincher's opening and ending sequences evoke its central dream analogy. ${ }^{4}$ The second section analyzes the way that Fincher's dynamic cinematic frame blurs the line between subject and object in order to create particular types of audience identification with diegetic elements. The third section explores the way that Fincher's presentation of violence in Fight Club evokes Rinzai Zen rituals and pedagogical methods aimed at inducing a visceral type of reflexive awareness conducive to Rinzai Zen master Hakuin's (1686-1768) three essential qualities, and ultimately, to awakening.

As for the narrow scope of this study, the emphasis is on the aesthetic effects of Fincher's interpretation, rather than on the so-called Buddhist-ness of the film or on the social, economic, political, or historical aspects of Rinzai Zen practice. ${ }^{5}$ Also, in order to focus more attention on the non-diegetic elements, the analysis omits description and discussion of the film's complex plot, other diegetic elements, or the many ways in which the film is simply neither "Buddhist" nor "Zen." For this reason, readers, who have neither seen the film nor have, at least, some outside knowledge of it, may find it difficult to follow. Please beware that the article also makes no effort to conceal the film's surprise twist in the end, so those wishing for an unspoiled viewing experience may wish to desist from reading until they have had a chance to watch the film. Finally, I will not discuss the theory of how Buddhist art generally aims to reveal Buddhist insights or the way that films can be understood as "revelatory" since other studies have addressed these complex topics and any contribution to that discussion would deserve more space than this short article allows. ${ }^{6}$

Methodologically, my starting point owes much to Francisca Cho's post-colonial, post-orientalist argument for Buddhism as an "instrument of my analysis rather than its target" (Cho 2017, p. 1). As Lina Verchery (2018, pp. 2-3) points out, this approach helps dismantle the problematic power dynamics implicit in "the traditional divide between 'theory' and 'data,' which makes the former the exclusive purview of scholarly authorities and relegates informants and religious 'insiders' to the latter." My focus on non-diegetic elements is informed by the Zen 'arts' or 'ways'-such as the way of flowers $(k a d \bar{o})$, the way of tea (chadō), and so on-which generally focus not on representing sacred content but on sacralizing secular content in order to transform perception and induce awakening. In my discussion of Fight Club, I refer to Fincher and his choices merely as a convenient way to focus on the film's non-diegetic aspects, and I do not mean to suggest that as director, he-rather than the book's author Palahniuk (1996), the screenwriter Jim Uhls, or the numerous other contributors-is the sole author, or even the main creative contributor, as some might interpret Astruc's auteur theory. Also, although Fincher's statements are occasionally cited in the footnotes, I do not suppose that his 'intention' is available in these statements, but rather disclose them insofar as they affect my own deciphering of the film's code, as Bourdieu [1968] (1993, chp. 8, p. 11ff, italics in original) states:

... the readability of a work of art for a particular individual depends on the divergence between the level of emission, defined as the degree of intrinsic complexity and subtlety, of the code required for the work, and the level of reception, defined as the degree to which this

3 In Zen Buddhism, the teacher and the practice methods-not some divine figure-discloses the true reality.

4 The abbreviation "Skt." is to distinguish the few Sanskrit terms in this article from the many Japanese terms, which are not indicated by any abbreviation.

5 I also do not subscribe here to Whalen-Bridge's idea that having one or more of the four possible causes-i.e., a Buddhist creator, subject, setting, or implication (Whalen-Bridge 2014, p. 55)—can help distinguish a Buddhist film from a "draftee."

6 For more discussion of these topics, see (Brant 2012; Cho 2017; Dorsky 2007). 
individual masters the social code, which may be more or less adequate to the code required for the work.

Hence, insofar as Fincher suggests that Buddhist codes undergird his 'emission' of Fight Club, my analysis of the generic codes that he references may help to raise the level of 'reception' of the film and, possibly, contribute to its appreciation. To that limited extent, this study might be considered an exercise in "aesthetic vision" (Cho 2017, p. 24)-i.e., "a way of seeing that has transcended the need for Buddhist forms and instead sees Buddhism in everything, including ostensibly non-Buddhist works of art" (Verchery 2018, p. 1) - that understands the film viewing experience in terms of lived religion and its implied logic of practice.

\section{The First Mysterious Gate: Frame and Emptiness}

The first mysterious gate of Zen involves clarifying disciples' conceptual understanding of Zen soteriology (Buswell 1986, pp. 223-26). According to the basic Buddhist framework, all sentient beings are in a constant state of dis-ease (Skt. duhkha) due to their unquestioned attachment to a single, lasting, and autonomous identity (Skt. atmya), in the futile search of which they endlessly take birth, age, and die in various painful realms of cyclic existence (Skt. samsāra). In order to become free from this cyclic existence, one must overcome attachment to identity by cultivating nonviolent behavior (Skt. śila), meditative concentration (Skt. samādhi), and wisdom (Skt. prajñā). But according to Mahāyāna Buddhist soteriology on which the syncretic Rinzai Zen school is based (Faure 1994, p. 14), everything within the realm of experience is like a dream in which seemingly distinct and separate subjects (i.e., beings) and objects (i.e., the world) are nothing but mental images empty (Skt. śunnya) of any inherent existence (Olson 2005, pp. 213-17). By systematically questioning the presupposed separate and distinct identity of all subjects and objects through the Buddhist path of self-reflection, sentient beings can wake up from the dream-like delusion that causes their nightmarish suffering and can realize awakening, which means to rest in the "nondual" state of reflexive awareness of enlightened Buddhas (viz "Awakened Ones"), who know the two-i.e., subjects and objects— to be mere aspects of a single mind aware of itself.

According to most Mahāyāna Buddhists, it takes numerous births and deaths over a period of three countless eons to transform one's perception to the point where one can rest effortlessly and blissfully in the state of complete, irreversible awakening. But, according to Rinzai Zen Buddhism, a teacher (rōshi) — who is considered to possess a purely altruistic motivation and skill in the various expedient means (Skt. upāyakauśalya) for communicating the ineffable experience of 'nonduality' in different contexts—can reveal to disciples the Buddha's "short-cut" to enlightenment through the three mysterious gates, namely through (1) teaching them basic principles; (2) giving disciples particular kōans to meditate upon, and using words in both a descriptive and performative way that is often paradoxical but not illogical; and (3) dealing them violent shouts or blows at appropriate moments to jolt them out of their sleep-walking mindsets into the reflexive awareness of awakening. ${ }^{7}$ When the disciples awaken to the blissful state of nirvāna, they discover not only that the sufferings of samsāra that vexed them never actually existed in the first place, but also that the Buddha and the teacher who appeared to help them escape samsāra were nothing but dream-like forms of the disciples' own externalized, yet dormant, buddha nature (Skt. tathāgatagarbha). For this reason, in Zen eschatology, rather than aim to gradually end the cycle of future births and deaths by becoming a buddha, disciples aim to realize instantaneously-like waking from a dream —-that their own mind already is a buddha by nature (Foster and Shoemaker 1996, pp. 91-94).

It is in this soteriological context that Lin-ji Yi-xuan provocatively admonishes his disciples:

7 For a debate over the role that violent Zen practices played in Japanese militarism, compare (Victoria 2006) with, e.g., a critique of Victoria's work, such as (Satō 2008). For a broader discussion of Buddhist justification of state violence, see (Jerryson 2018). 
Followers of the Way, if you want to get the kind of understanding that accords with the Dharma, never be misled by others. Whether you're facing inward or facing outward, whatever you meet, just kill it! If you meet a buddha, kill the buddha. If you meet a patriarch, kill the patriarch. If you meet an arhat, kill the arhat. If you meet your parents, kill your parents. If you meet your kinfolk, kill your kinfolk. Then, for the first time you will gain emancipation, will not be entangled with things, and will pass freely anywhere you wish to go." (Park 2008, p. 102; Ch'en 1973, pp. 357-58).

Here, Lin-ji's figurative and iconoclastic injunction for his disciples to "kill" everyone including the founder of their own religion-something that sounds to most Buddhists like an inauspicious and terrible thing to say-uses shocking language as an expedient means (Skt. up $\bar{a} y a$ ) to make disciples question their dualistic assumptions about the nature of the path to awakening and, through a nonconceptual, instantaneous glimpse of its nondual nature, to wake up from their dream. But it also serves as an implicit instruction for disciples on the Buddhist path to try repeatedly to see through any and all identities, whether of ordinary beings or of buddhas, and to realize themselves and all beings to be nothing but deluded constructs of a single dreaming mind (Foster and Shoemaker 1996, pp. 91-94).

David Fincher's idea that "on the path to enlightenment you have to kill your parents, your god, and your teacher" follows a modern Zen master's interpretation of Lin-ji's statement (Reed 2007, p. 15). Although Fincher himself does not clarify his own relationship to the Buddhist teachings that he describes, he effectively frames Fight Club as a coming of age story about Jack, an everyman escaping from his painful cyclic existence with the help of Tyler Durden, a Zen-teacher-like figure, who forces Jack to question the distinct and separate identities that he ascribes himself and others in order to wake up from his dream. ${ }^{8}$ According to Fincher, the film begins at the point where Jack already has "killed off his parents" (Smith [1999] 2014, p. 60), meaning that he has already realized that happiness cannot be found in the world by becoming something normative that he can never be. After meeting Tyler Durden, he learns to "fly in the face of god" (Smith [1999] 2014, p. 60), meaning that Jack begins to free himself through an antinomian path. After maturing and advancing along this path, he sees that he "has to kill off his teacher Tyler Durden" (Smith [1999] 2014, p. 60), meaning that he must destroy that part of himself which has dreamed up the teacher to help him escape the nightmarish existence that he has created for himself. Finally, by the end of the film-when all the buildings in Jack's dreamworld come crashing down-he realizes his own buddha nature, thereby killing the buddha qua ideal separate from his own nature.

In Fight Club, Fincher does not explicitly spell out the Rinzai Zen soteriological framework or its dream analogy, but communicates its essential elements through metaphor and mimesis (Smith [1999] 2014, p. 62). That is to say, since movie watchers enter the theater already primed to immerse themselves in an illusory film world as a means of escaping their own mundane existence, once the film begins, they are immanently able to identify with that aspect of Jack's journey to enlightenment which involves his own wish to escape his mundane existence by immersing himself in a world that he eventually realizes is illusory. But in order to make the audience self-consciously aware of the illusory or dream-like nature of the film world, Fincher frames the entire narrative within two bookends-the opening credit sequence which shows the film world emerging from Jack's brain and the closing credit sequence where the image of the crumbling buildings is interrupted by a hard cut to black and the Pixies song "Where is my mind?"- - that function to bracket the entire narrative and the "identities" within it as mere externalizations of Jack's confused subjective experience, like the empty sights and sounds of a dream that lacked any objective reality from the beginning, as Fincher states:

8 I adopt here the convention of referring to the main character as "Jack," as he is called in the screenplay, even though he was deliberately unnamed in both the book and the film. 
... it's a metaphor, it's not about a real guy who really blows up buildings, it's about a guy who's led to feel this might be the answer based on all the confusion and rage that he's suffered and it's from that frustration and bottled rage that he [first] creates Tyler. And he goes through a natural process of experimenting with notions that are complicated and have moral and ethical implications that the Nietzschean übermensch doesn't have to answer to. That's why Nietzsche's really great with college freshman males, and unfortunately doesn't have much to say to somebody in their early thirties or early forties. And that's the conflict at the end-you have Tyler Durden, who is everything you would want to be, except real and empathetic. He's not living in our world, he's not governed by the same forces, he is an ideal. And he can deal with the concepts of our lives in an idealistic fashion, but it doesn't have anything to do with the compromises of real life as modern man knows it. ${ }^{9}$

Hence, although some might interpret the film's ending as satirically portraying or portending Jack's mental breakdown or a social apocalypse, Fincher describes Jack, positively, as awakening from his nightmare into real life, much like the classic depiction of a Zen practitioner ultimately returning to the real world from years of idealistic religious practice. Thus, Fincher appears to envision the film's final bookend as helping the audience to retrospectively fill in the blanks and - whether or not they understand the soteriological framework as Jack's journey unfolds-to possibly feel at the end as though they too have awakened from their own dream as they return to their lives outside the film viewing environment.

\section{The Second Mysterious Gate: Identity and Identification with Kōans}

In the second mysterious gate of Rinzai Zen, the teacher gives disciples a series of kōans to contemplate (Buswell 1986, p. 225; Kapleau 1988, p. 56). Contrary to the popular notion of kōans as unsolvable meaningless paradoxes, kōans, in contemporary Japanese Rinzai Zen practice, are "enigmatic and often shocking spiritual expressions based on dialogical encounters between masters and disciples" (Heine and Wright 2000, p. 3; Hori 2000, p. 304) which, in trying to express the inexpressible, serve as pedagogical tools for developing insight into the illusory nature of the distinct identities to which beings are attached. From among the five categories of kōans-which can be short or long, simple or complex - the teacher first tells disciples to contemplate a "breakthrough" (shokan) kōan, (Kraft 1988, pp. 74-75; Mohr 2000, pp. 264-65) such as, "You know the sound of two hands clapping; what is the sound of one hand clapping?"10 While disciples contemplate this kōan's "punchline" (watō) (Schlütter 2000, p. 178)—e.g., "sound of one hand"—during periods of meditation and monastic work (samu) (Hori 2000, pp. 288-92), they meet regularly with their teacher in private encounters (dokusan). In these encounters, the teacher guides the disciples to realize the kōan and also judges when they finally have a genuine "breakthrough" glimpse (kenshō) of buddha nature through reflexive awareness. Finally, after disciples have this first glimpse, they move on to contemplating the other four categories of kōans until they realize complete awakening.

According to Rinzai Zen, one needs to actually do the kōan practice in order to truly understand what a kōan is and the mystic process through which it is supposed to lead to an ineffable, breakthrough glimpse. For that reason, to elucidate the second mysterious gate, this section of the paper will focus instead on demonstrating the way that a monk's lived experience of contemplating a kōan might be said to resemble that of the audience watching Fight Club. To this end, the following discussion will juxtapose the experience of a monk during the three-step "breakthrough" process described by Victor Sōgen Hori, a former Rinzai monk, with that of a viewer during the three shifts in David Fincher's

9 See Van Der Braak (2011) for a discussion of how Nietzsche and his notion of the übermensch were influenced by his limited reading of Buddhism.

10 This is also called a hosshin (Skt. dharmakāya) kōan. 
cinematic frame, which functions-wittingly or not like a Zen teacher-first, as a window, then, as a doorway, and finally, as a mirror (Elsaesser and Hagener 2010).

\subsection{Divided Seeing-Cinematic Frame like a Window}

After receiving the kōan, "You know the sound of two hands clapping; what is the sound of one hand clapping?" a monk is traditionally told to contemplate it but receives very little if any theoretical instruction about how to do so, as Hori explains:

At first the monk expects that the answer to the kōan will one day appear before him like the solution to a riddle. That is to say, he thinks it would be an object of consciousness, an object of seeing. This is what would be expected if he were trying to understand it intellectually. But constant repetition of the kōan imprints the kōan into his consciousness so that the kōan no longer is merely an object of seeing, but colors his very seeing (Hori 2000, p. 288).

Here, Hori describes the ordinary starting point for contemplating "the sound of one hand," where the monk intellectually conceives of his own mind as the subject who will perceive the meaning of the punchline as an object to be perceived. Since the point of contemplating the kōan is to become free of perceiving a distinct subject and object, the teacher gives the monk the advice that the kōan is "not a question to be answered by intellectual thought" but rather something to "identify" with or "become one" (narikiru) with through repeating it to oneself. With this advice, the kōan begins to imprint itself deeper in the monk's subjective mind as it seeks to understand the nondual nature of reality and thereby, to answer the kōan.

In Fight Club, until viewers realize that Jack and Tyler Durden are not different persons, they may not see that Fincher's opening credit sequence and first scene-which use subjective non-diegetic music and voice-over narration in contrast to objective camera angles—set up a complex kōan that will serve, like the "Sound of One Hand" kōan, to induce in Jack and the audience insight into the illusory nature of "subjective" identity and "objective" reality. ${ }^{11}$ At first, an objective camera angle shows credits dissolving in and out against the backdrop of a synaptic labyrinth inside an unidentified brain whose neurons are firing, in an apparent attempt to respond to as-yet-unrevealed danger indicated by the non-diegetic record scratch and blaring music. After the objective camera appears to track backward continuously through the neurological interstices-using match-cuts over black-it passes out of the brain along the top of the skull across a sweaty forehead, as though a fearful thought were pushing its way out from the internal space of the brain into the external objective reality. ${ }^{12}$ As it continues to track backward along the top of a gun's shaft, it notably comes to rest in an extreme close up of Jack's fearful face, gun-in-mouth, from the subjective perspective of the as-of-yet unidentified figure, Tyler, who the audience assumes to be the object of Jack's fear but is told, moments later, that the real source of Jack's immediate danger is that the bombs Tyler planted will destroy the city in "three minutes" if Jack cannot solve the kōan about Tyler's identity that he is apparently contemplating. ${ }^{13}$ Since Fincher's camera has shown only objective angles up to this point in the film, the audience does not read this first subjective angle as a POV shot and generally regards the cinematic frame as a "window" or a windshield in a moving vehicle through which the film world is represented objectively. In contrast to the overall frame, Jack's subjective perspective on that world is expressed through images of Tyler, in which his face is obscured, and through Jack's ironic voice-over, which causes the audience to feel they are inside Jack's head. Since Fincher presents Tyler and Jack as two separate and distinct characters interacting with each other in the same objective reality—like two hands clapping—viewers might initially get the irony of Jack's first words, "People are always asking me if I know Tyler Durden" but they do not get

11 See Dorsky (2007) for more on the after-effect of watching films in theaters.

12 Cf. (Smith [1999] 2014, p. 62)) "I liked the idea of starting a movie from thought, from the beginning of the first fear impulse that went, Oh shit, I'm fucked, how did I get here?"

13 The "three minutes" before the bombs go off serves as a self-conscious Macguffin that drives the story forward. 
how his words are expressing the inexpressible, namely that Jack's interaction with Tyler here is just the sound of one hand clapping. Whatever the case, like the initial experience of the monk described by Hori, viewers naturally expect that the answer to whether Jack knows Tyler-whatever "knows" might mean here-will be shown to them in the film "like the solution to a riddle" as though it were "an object of consciousness, an object of seeing" that they will be able to understand "intellectually" (Hori 2000, pp. 288-89). But later, when viewers realize Jack and Tyler to be the same person, how will they intellectually understand the seemingly paradoxical nature of the objective angles of this scene's window-like frame and its relationship to the subjective voice-over? ${ }^{14}$

In order to help the audience identify with Jack in his contemplation of his own kōan about the way he interacts with himself qua Tyler, Fincher-like a Zen teacher first advising a monk to identify with the kōan rather than try to answer the question intellectually-immediately draws into question the seeming objectivity of his cinematic frame by spontaneously moving the camera in a stylized way to portray Jack's explanation of the various underground locations of bombs ready to explode. With the camera's high-speed whip pans, tilts, boom-downs, and steady-cam shots, connected by match-cuts over black to make the camera seem to move seamlessly through multiple concrete barriers, the cinematic frame remains a window. But instead of depicting Jack's brain objectively as before, it now presents the objective content of his subjective images through camera movements that help the audience sense and identify with the subjective speed and unrestrained quality of Jack's thought. At first, the audience-who is expecting an answer to Jack's central question about whether he knows Tyler-understands the content with the frame to represent Jack's memory of an "objective" reality. But since Jack's voice-over states, after the sequence ends, that he knows about the bombs "because Tyler knows" about them, the audience-who presumes Jack and Tyler to be separate and distinct identities-reinterprets the frame as presenting Jack's "subjective" imagination about something which Tyler must have told him. Thus, through Fincher's window frame, the audience identifies with Jack's contemplation of the kōan no longer as a mere object of seeing, but as coloring their very seeing (Hori 2000, pp. 288-89). ${ }^{15}$

\subsection{Identification Process_Cinematic Frame Like a Doorway}

In this second step, Hori explains that when the kōan eventually ceases to be even an object of the monk's attention, it simply becomes part of his sub-conscious mental chatter, as follows:

Eventually, without conscious effort the kōan "Sound of One Hand" always rises to consciousness, repeating itself over and over again, whenever attention is not fixed on anything else. This is a recognizable early stage in narikiru, in becoming one with the kōan. "Sound of One Hand" has so invaded his consciousness that it is no longer the object of attention in consciousness, but forms the background for whatever else is the object of attention (Hori 2000, p. 288).

As the monk repeats the kōan to himself, he eventually comes to identify with the kōan to some degree, but the identification process is not complete, because the monk still assumes dualistically that "becoming one with the kōan" means that a separate, distinct "I" qua subject and meaning qua object somehow merge. Although the monk still has no insight into the punchline, he is, at least now, totally immersed in the contemplation of it.

Likewise, after viewers first experience the camera's subjectivity in the bomb scene described just above, Fincher's cinematic frame shifts to function more like a "doorway" through which viewers

14 My reason for calling the use of voice-over narration "non-diegetic" here is to distinguish it from a more "diegetic" narration motivated within the story like, for instance, in the film Double Indemnity, where Fred McMurray confesses into a microphone on screen.

15 Cf. Smith [1999] (2014) “Because the movie is about thought, it's about how this guy thinks. And it's from his point of view, solely." 
enter Jack's subjective world—particularly when Jack launches into his confused story about how he first came to "know" Tyler as a result of his unhealthy relationship with Marla (played by Helena Bonham Carter), who disrupted the peace he had found by attending self-help group meetings and learning to meditate to overcome his crippling anxiety and insomnia. To help the audience further identify with Jack's story and to make the subjective nature of the cinematic frame clear, Fincher uses Jack's voice-over as motivation for a flashback by pushing the camera slowly in on Jack's face. But rather than use the standard storyteller's trope of a slow subjective dissolve for a window-like transition to the past, Fincher's camera pauses in a medium close-up of Jack who suddenly jerks his head to the right in narrative present time, from which Fincher match cuts to his head landing from the left oddly on the big chest of Bob (played by Meatloaf) rather than Marla-as though Jack has been non-diegetically pulled along with the viewers through a doorway into the narrative past. ${ }^{16}$ Since Jack's awkward jerking movement is not motivated by any diegetic element, Fincher's abrupt subjective transition blurs the line not only between past and present but between the non-diegetic cinematic frame and Jack as a diegetic character. While Fincher's subsequent camera movements follow Jack's stream-of-consciousness, the subjectivity of the camera forms the "background for whatever else is the object of attention," yet by drawing attention to itself, it "rises to consciousness, repeating itself over and over again" (Hori 2000, p. 288). For instance, when the voice-over narration suddenly self-consciously states "Wait ... Let me start over"- at which point Fincher cuts to a medium shot of Jack suddenly pulling back from the hug, Jack's face becomes confused as though he, as a diegetic character, suddenly heard his own non-diegetic narration of the flashback, and this confusion motivates the next jump cut into a new, presumably prior, flashback space. Through this transition, the audience understands now, subconsciously, that the camera only represents the erratic mind of Jack, an unreliable and confused narrator. ${ }^{17}$ Since viewers have fully entered the doorway into Jack's mind, they come to identify his subjectivity with that of the camera. Thus, the central kōan becomes the repeated subjective activity of the camera, which is "no longer the object of attention in consciousness, but forms the background for whatever else is the object of attention."

\subsection{Subject and Object are the Same-Cinematic Frame Like a Mirror}

In this third step, Hori describes the monk's "breakthrough," which is a complete transformation in the monk's way of perceiving the kōan as object and his own consciousness as subject, as follows:

Finally, there comes a moment when the monk realizes that his very seeking of the answer to the kōan, and the way that he himself is reacting to his inability to penetrate the kōan, are themselves the activity of the kōan working within. This is the difficult point to explain. The kōan is not merely a static entity, something with a fixed self-nature to be apprehended. If anything, it is an activity, the activity of seeking to understand the kōan which uses the monk and his mind as its arena. The kōan is both an object of consciousness and the subjective activity of consciousness seeking to understand the kōan. The monk himself in his seeking is the kōan. Realization of this is the insight, the response to the kōan. He "realizes" the kōan in both senses of the word "realize." On the one hand, it is a cognitive recognition, but on the other, it also "makes real," since the cognitive recognition could not have occurred unless he himself instantiated the unity of subject and object (Hori 2000, pp. 288-89).

Here, the monk is aware that his mind has no separate identity within which the kōan is somehow operating subconsciously but rather the kōan's appearance is ironically just a reflection of his own

16 Marla's precise role in Jack's journey is not central to this paper. But she might be read as representing the world that Jack would like to relate to but cannot-except by being Tyler-until the film's end.

17 Cf. (Smith [1999] 2014, p. 61)) "It's as erratic in its presentation as the narrator is in his thinking." Also (p. 62), "We take the first forty minutes to literally indoctrinate you in this subjective psychotic state, the way he thinks, the way he talks about what's behind the refrigerator, and you go there." 
mind. Hence, the monk's realization is like seeing the humor in the punchline of a cosmic joke. But instead of laughing at this punchline, he experiences a liberating, wide-eyed awakening in which the nature of mind is recognized for the first time. Next, Hori summarizes the monk's shift from his dualistic perception in the first step, to his glimpse of non-dualistic reflexive awareness in the third step, as follows:

At first there was a subject of consciousness trying to penetrate a kōan which was treated merely as an object of consciousness. Subject and object-this is two hands clapping. When the monk realizes that the kōan is not merely an object of consciousness but is also he himself as the activity of seeking an answer to the kōan, then subject and object are no longer separate and distinct. He has become one with the kōan, or perhaps it is more accurate to say, the kōan has become one with him. This is one hand clapping-nairikiru "becoming one" (Hori 2000, pp. 289).

In the third step, in order to help the audience identify with Jack's insomnia making him suffer from being unable to relate empathetically to others or to even differentiate between his waking and sleeping reality, Fincher's cinematic frame shifts to become a "mirror" of Jack's unclear state of mind in which everything seems like a mere reflection of his suffering and it becomes difficult to distinguish what is subjective from what is objective. To establish this mirror-like frame within the flashback, when Jack's voice-over states "With insomnia, nothing is real," Fincher begins to blur the line between the subject and object appearing in Jack's own mind-screen. Fincher does this by jump cutting, first, to a close-up objective angle on a Starbuck's cup as the camera tracks back and forth, and then to a reverse objective angle on Jack standing pallid in an office, so that the audience now realizes that the first objective angle on the Starbuck's cup was actually a subjective angle from the POV of a copy machine moving back and forth while making copies. Next, Fincher uses a similar, jump-cut transition to an extreme, wide angle close-up of pieces of trash from a seemingly objective angle, but, as before, the camera pulls back to reveal that the "objective" shot is actually just expressing Jack's "subjective" experience of a delusional daydream. Finally, in the scene where Jack's imagination takes over while he is looking at an IKEA catalogue, Fincher cuts to a wide angle pan of Jack's empty apartment while the same IKEA furniture that Jack saw on the matching two-dimensional catalogue page magically comes to be reflected in frame, piece by piece, along with the printed IKEA names and prices that are superimposed on them. ${ }^{18}$ But then, Jack walks into the seemingly two-dimensional representation portrayed in his own subjective mind-screen. This makes the two-dimensional space seem at once two-dimensional and three-dimensional, while removing all distinction between Jack's subjective and objective realities.

But to further capture the irony of this mirror, Fincher's cinematic frame reveals itself to be a "two-way mirror" so that the audience becomes reflexively aware of their own position in the so-called "real" world where they are watching the film and also comes to feel as though the characters in the story are looking directly at them. To this end, in the scene where Jack describes Tyler's legendary days working as a film projectionist, Fincher uses a freeze-frame close-up of Tyler while Jack's voice-over states, "Let me tell you a little bit about Tyler Durden," in order to motivate a re-enactment (rather than a flashback). In the re-enactment, both-i.e., Jack qua subject telling the story and Tyler qua object about whom the story is told - end up directly addressing the camera in a way that not only breaks the fourth wall but pushes viewers to become self-consciously aware of their own mental processes and physical location watching the film, as though they are looking into the mirror and seeing their own reflections looking back at them. For instance, when Jack speaks about diegetic spectators in a movie theater and shows them having a two-frame image of a man's penis forced upon them, the audience watching Fight Club not only comes to see themselves reflected on-screen but also feels as though

18 Time code 04:53 marks the beginning of the IKEA scene. 
they are being trolled because Fincher inserts a jump-cut to a two-frame medium close-up image of a man's penis, which is shocking both to the diegetic audience and the spectators watching Fight Club. In this way, Jack and Tyler no longer appear to be mere diegetic characters within either an objective or subjective film world, but rather seem like emissaries sent by David Fincher to enter the space of the "real" world and humorously mock the audience's conception of themselves as separate and distinct subjects. Furthermore, the audience not only comes to fully instantiate the unity of subject and object within their own being but they also become reflexively aware that the initial dualistic viewing experience through the cinematic frame as a window merely set up the punchline of the kōan, which expresses the inexpressible nondual experience of the two-way mirror. Thus, by freely transgressing and 'selflessly' mocking the film's own narrative conventions, Fincher undermines the fixed, passive identity assumed by the audience and introduces them to joy of watching a film with open, present, receptive, and reflexive awareness for whatever arises next. If, at this point, the audience does not have the full "breakthrough" glimpse of nondual reflexive awareness as described in Zen, they are, at the very least, primed for Fincher's skillful revelations in the next mysterious gate.

\section{The Third Mysterious Gate: Identification and Dissociation through Violence}

According to an oft-told story, whenever Lin-ji Yi-xuan had private encounters with his teacher Huang-po, he was repeatedly beaten and sent away, until he finally despaired, gave up, and left. When Lin-ji told the Master Ta-yu about all the beatings he received from Huang-po, Ta-yu praised Huang-po's great kindness, causing Lin-ji to realize that the violent beatings had just been Huang-po's skillful means for pointing out the way that his own ordinary mind already is the buddha. As soon as Lin-ji reflected on the state of awareness he experienced in the beatings, he instantaneously attained awakening and exclaimed, "There is nothing special about Huang-po's teaching!" Upon hearing this outburst, Ta-yu immediately struck Lin-ji for his seeming irreverence, but Lin-ji, who had intended no insult, responded without missing a beat by giving Master Ta-yu three blows to the ribs (Olson 2005, pp. 232-33), thereby affirming his own enlightened understanding. In this way, violence was both a trigger for Lin-ji's awakening and a spontaneous expression of it.

Lin-ji's story is usually told to explain how violence came to be enshrined in the Rinzai school's “Third Mysterious Gate" (Buswell 1986, p. 226; Kapleau 1988, p. 59), which is traditionally said to consist of "shouts and blows." In modern Rinzai Zen, the teacher is considered to be like an unbiased judge, meting out timely and appropriate-but unconventional, spontaneous, and sometimes violent-responses to disciples that wordlessly express the inexpressible and lead receptive students to awakening. When Zen disciples are at the entry level, the teacher's or his emissaries' shouts and blows are understood as challenging disciples to commit themselves steadfastly to the path, breaking down their attachment to identity, building qualities such as courage and resourcefulness, and deepening their appreciation for the teacher's wisdom and skillful means (Sōkō 1988, pp. 25-28; Kapleau 1988, pp. 44-50). When the disciples are at the advanced level, the teacher's shouts and blows are understood as effectively shocking disciples out of their unreliable, dualistic and conceptual way of seeing into a state of nondual reflexive awareness that is conducive to awakening. Whether or not disciples see the immediate purpose of the violent methods, they are ideally supposed to consider them compassionate acts undertaken purely for their own benefit, not some type of self-centered physical or verbal abuse of others, from which all Zen practitioners of non-violence are clearly enjoined (Sōkō 1988, pp. 16-19; Kapleau 1988, p. 61; Kraft 1988, pp. 79-81). In this way, Zen disciples mentally associate the violence with the seemingly miraculous, wordless, mind-to-mind transmission (yixin chuanxin) of spiritual awakening from teacher to disciple (Faure 1994, p. 11). Thus, beyond mere glorification within the traditional legends, violent pedagogical methods are considered essential to a teacher's expression of his or her enlightened skill-in-means and to disciples' paths to awakening.

In actual practice, the violence in Japanese Rinzai Zen Buddhism is, according to Bourdieu's rubric, both (a) "symbolic" i.e., "the imposition of systems of symbolism and meaning (i.e., culture) upon groups or classes in such a way that they are experienced as legitimate" (Jenkins 1992, p. 104) 
and (b) "overt" insofar as it is physically enacted on disciples through various rituals-e.g., upon entering a monastery, in beatings by a wooden staff (kyōsaku) during meditation retreats, and in the private encounters (dokusan) —as a skillful means for changing their habitus, i.e., "the basis of perception and appreciation of all subsequent experiences" (Bourdieu [1977] 1995, p. 22). ${ }^{19}$ Since virtually no novice monks initially enjoy being shouted at or struck, the third mysterious gate, practically speaking, relies upon disciples trusting the personal value of monastic violence and learning to appreciate the shouts or blows as ultimately helping them to dissociate themselves from the impulses of their 'fight or flight' instincts and to identify themselves instead with the buddha-like, transcendent-yet-immanent state of nondual reflexive awareness. While genuine appreciation for these violent methods might be rare in Rinzai Zen monasteries and might seem, from a Western psychological perspective, like an impossibility, the deep sense of appreciation and reverence for the process that is expressed by some monks within the lived tradition is palpable and profound, as Morinaga Sōkō explains:

The relationship between master and disciple must be so close and so strong that not even a single hair can be inserted between them. It might be compared with sumo wrestlers in the ring. Huge men weighing over three hundred fifty pounds can crash into their opponents with all their might only because they have absolute confidence that the ring in which they fight will not give way beneath them. In Zen training the "I" must at all costs be broken. But this tenacious " $\mathrm{I}$ " cannot be conquered in a timid fashion. Nothing will come of the training unless you dig in your heels and hang on despite being scolded, struck, or threatened with expulsion (Sōkō 1988, pp. 22-23).

Although this justification of violent methods describes an ideal that is certainly not the experience of all monks and might seem romantic, Sōkō's first-hand description of entering Daitokuji monastery shortly after the second world war shows a more sobering side (Sōkō 1988, p. 28) of the violent ritual of niwazame, i.e., testing disciples requesting admission to a monastery. In niwazame, prospective disciples are not only repeatedly denied entry and made to sleep outside the monastery gates for days before being admitted, but also scolded and beaten before being accepted. Since niwazame is understood to symbolize the hardship undergone by the first student of Zen, Sōkō says, "I thought this ritual was a matter of form and did not suspect the real severity of it." But, after being denied his first entry request, Sōkō describes the response to his second request, as follows:

After a while another monk appeared, armed with an oaken staff. "You were refused entrance, and yet you are still here, an eyesore to all. Please get out at once." When I made no move to leave, the monk changed his tone. "Deaf or something?" he shouted, and with blows and kicks he sent me flying out of the gate. When I peered back inside I saw the monk had disappeared again. So I crept back stealthily and took up my position at the bench. This sequence was repeated several times" (Sōkō 1988, p. 26).

Even though Sōkō had great faith in the Rinzai tradition, had prepared for this violent test, and had thought his resolve was unshakeable, he says:

At the beginning I was able to put up with it because I thought it was a form I must follow. But gradually I started to get angry-they seemed to be laying it on a bit thick against someone who was putting up no resistance. By evening my anger had disappeared, and instead I felt utterly forlorn ... my resolve had already begun to falter in face of the misery and turmoil which had welled up in me. I was discovering that an individual's strength of will is extremely weak (Sōkō 1988, p. 26).

19 In postwar Zen monasteries and practice centers, especially in America, there is no sense of these "beatings" as punishment. Some Zen monks say they find these blows refreshing, rather than painful. In some places, meditators put their palms together and ask to be hit with the stick so as to clear up their fogginess or sleepiness, although macho behavior can also occur. 
Here, the fact that Sōkō put up "no resistance" is an important part of the Zen training which helps monks "enter the monastery completely emptied, humble, and compliant" (Sōkō 1988, p. 27) and gives them a small taste of the nondual Buddhist experience of immanence and transcendence, similar to-to borrow a Christian phrase-courageously turning the other cheek. Clearly, Sōkō struggled at first and questioned his own resolve, but eventually made it through, as he reports:

My niwazame lasted three days. By the end my face was congested with blood. All my teeth felt loose, my eyes felt as though they were popping out of their sockets, and my hips felt as if they had been wrenched out of joint. I had come to Daitokuji on the first of March, and it was bitterly cold that year. All I had on my feet were sodden straw sandals. The cold had risen from my toes to my thighs-my legs had become completely frozen and numb. I think it was an act of real courage to go on and on in this state, pulling myself back from the brink of exhaustion and despair to carry through with my vow to practice Zen (Sōkō 1988, p. 27).

Here, the shocking thing is not so much Sōkō's description of the effects of being beaten-which, of course, could be much worse-but the fact that he willingly involved himself in such scolding and beating through fifteen years as a Zen monk and then later as a teacher, as he says:

Had I not learned these lessons at Daishun and the entrance to Daitokuji, I doubt that a half-hearted young man in his twenties would have found the strength to persevere in a Zen monastery. However much society may change, I am convinced that Hakuin's three essentials constitute the cornerstone of all achievement (Sōkō 1988, p. 29).

In this way, Sōkō argues that, in order to succeed on the path, a monk must develop Hakuin's three essentials for Zen practice-namely, the great root of faith, the great ball of doubt, and the fierce tenacity of purpose (Sōkō 1988, p. 28) —through being tested and awakened by violent rituals. Then, after presenting his justification of the violent monastic pedagogy - which entails training in both being hit by others and hitting them-and then expressing his acquired appreciation for the skillful means that led him personally to awakening (Sōkō 1988, pp. 28-29), Sōkō concludes:

What I consider most important is that each individual lives a truly fulfilled and contented life, at peace even in the face of death. That is the primary aim of Zen, no matter how foreign its external form may at times appear (Sōkō 1988, p. 27).

In Sōkō's conclusion, he does not explicitly connect these violent pedagogical methods with the Zen transmission of awakening through pointing out the nondual nature of mind, probably because he does not deem such a topic suitable for an uninitiated audience. However, he implicitly suggests that they are indispensable to the third mysterious gate, since this is considered the only way to truly achieve complete "peace even in the face of death." Thus, if one reads Sōkō's argument carefully, it seems that, contrary to the popular Western notion of Zen as an inherently peaceful religion, he considers violence to be central not just to Rinzai Zen pedagogy, but to its soteriology, and to that extent, it is something not to be ignored or discarded by modern practitioners wishing to experience awakening through the Rinzai path. ${ }^{20}$

Although Sōkō's argument is not specifically mentioned by Fight Club's creators who may have only a cursory knowledge of Rinzai Zen, it would seem to resonate well with the film's implication that modern culture is suffering spiritually, due to its having lost touch with immediate, physical, life-and-death challenges. And, the premise of the "fight club" itself certainly echoes Sōkō's implicit notion that exposure to violent rites of passage and daily physical threats makes it easier to overcome one's personal suffering, transform one's perception of the world, and live "a truly fulfilled and

20 For recent Western studies attempting to disabuse Westerners of this popular misconception, see, e.g., Victoria (2006); Jerryson and Juergensmeyer (2010), which point to occasions where Zen Buddhist notions of pure motivation and skillful means have been used to justify various types of aggressive behavior, physical abuse, and even military warfare. 
contented life, at peace even in the face of death" (Sōkō 1988, p. 27) as, for example, Ed Norton (who portrayed Jack) states about Fight Club in an interview for Premiere Magazine:

In Buddhism, there's Nirvana, and then there's Samsara, the world of confusion and disharmony. That world [of Samsara] is our testing ground, where we have the experiences that help us become enlightened. I'm not saying "Fight Club" is The Book of Living and Dying, but it was kind of that idea: You're challenging yourself to break out of the world [of Samsara] (Schneller 1999, bracketed insertions mine).

Hence, since Fincher describes the overall story in light of Lin-ji's violent path to enlightenment and since Ed Norton likens Jack's participation in the fight club's violent rituals to "experiences that help us become enlightened," it is not unreasonable to assume that the film's creator-contributors might have, at least, wished film viewers to become (more) enlightened through watching the film, due to their identification with Jack on his journey and their implicit consent, as film viewers, to being vicariously tested and, perhaps, shocked into awakening by the graphic on-screen violence.

But, however one interprets the intentions of the film's creators, the purpose of our discussion here is not to decide whether the film is truly Zen but to decipher the code of violence presented in Fight Club insofar as it can be read as mimicking aspects of the third mysterious gate. And to this end, although some people might interpret Fight Club's form of mimicry as an oblique critique of the Rinzai Zen Buddhist religion-especially since Jack seeks in the end to escape the fight club and its more violent offshoot "Project Mayhem" - I would argue that the film can easily be interpreted in line with the humorous and iconoclastic tendencies of Rinzai Buddhism itself (Olson 2005, p. 231). Hence, even though the film might be read, for instance, as raising concerns about the potential for corruption and abuse in Zen-like religious institutions-and, granted, the film's creators probably would agree that draconian and abusive pedagogical methods have a questionable place in modern society-such a reading would seem to neglect the fact that Rinzai Zen Buddhism abounds with similar critiques of its own religious forms. ${ }^{21}$ For example, it is said that when master Ikky $\bar{u}$ was invited to consecrate a new bodhisattva Jizo statue, he stood before the devoted crowd of villagers gathered for the special occasion, calmly lifted his robes, and proceeded to urinate on their valuable religious icon (Olson 2005, pp. 231-32). This story, whether true or not, is recited in Zen circles not to suggest that Ikkyu was disavowing the religion through which he attained awakening, but to invoke his wry, iconoclastic critique of one of the ways that the religion's own aims get sidetracked by 'religious' tendencies to view enlightenment as a distant blissful destination, rather than something spontaneous and available right here, and now. Similarly, given that the film presents Jack as becoming enlightened through the violence central to the fight club, the film's seeming satire of the fight club qua cult can be read not as an invective against religion per se, but as a mimetic form of Zen iconoclasm that challenges Jack and the audience to "kill" anything with which they identify—even if it appears to be a buddha-since this leads to the final stage of Zen practice, which the famous Zen oxherding pictures depict as a return from religious to worldly life (Suzuki 1960, p. 170), much in the way that the film suggests Jack returns to society holding hands with Marla.

Whether or not this general interpretation is correct, my subsequent analysis of Fight Club will focus on sketching out the specific way that Fincher's presentation of violence evokes Sōkō's experience of niwazame. Due to space concerns, I will focus on only a few key scenes which function like a Zen teacher gradually initiating viewers into a Zen-like appreciation for violence as a path to enlightenment so that they can identify with Jack qua disciple being introduced gradually to the third mysterious gate by his teacher Tyler. Since Sōkō frames his own appreciation for the violent rituals in terms of Hakuin's three essentials for Zen practice, the following discussion will be framed in these terms too.

21 According to (Reed 2007, p. 16)), many of the film's critics initially panned Fight Club due to its violent content. However, since these critics praise other films which show even more graphic violence, I would argue that their negative reviews were due not to the violence itself but to their distaste for Fincher's presentation of it. 


\subsection{The Great Root of Faith}

The great root of faith means trusting one's teacher and the tradition he represents. It also means believing in the limitless potentiality that lies within oneself (Sōkō 1988, p. 28).

According to Sōkō, before he could benefit from the violence of the monastery, he needed to understand the ancient lore of the Rinzai Zen tradition on which it was based and to develop the strong foundation of faith in his teacher who sent him there.

In the Fight Club scene where Tyler first initiates Jack into the violent soteriology of the fight club, his words, "I want you to hit me as hard as you can," gives Jack pause, as it would anyone, and this is formally expressed by a freeze-frame, close-up on Tyler's face. But before Jack complies with his instruction, Fincher demonstrates Jack's "root of faith" in Tyler by using Jack's voice-over to motivate a jump-cut to the sequence recounting Tyler's legendary life as an antinomian hero. In this re-enactment scene-which includes the shocking two-frame image of a man's penis as described above-Jack's awe of Tyler resembles a Zen disciple's awe of his teacher's realization of emptiness that expresses itself in unconventional, spontaneous, and shocking words and actions for the benefit of others. ${ }^{22}$ By inserting this scene right before the first depiction of violence, Fincher helps the audience identify with Jack's faith in Tyler and the antinomian tradition into which he is initiated. When the re-enactment ends, Tyler convinces Jack of "the limitless potentiality that lies within oneself" by asking rhetorically, "How much can you know about yourself if you have never been in a fight?"

In order to portray Jack's development of faith further into the "absolute confidence" necessary for genuine teacher-disciple relationship like sumo wrestlers slamming into one another as Sōkō describes it, the subsequent fight scene-which starts with a medium close two-shot of Jack's and Tyler's first awkward punches presented almost farcically and ends with a long shot of them fighting noisily in an empty parking lot late into the night-immediately jump-cuts to a reaction shot of the two of them happily drinking a beer together, while Jack says "We should do it again some time." In this way, Fincher shows the way that Jack's faith in Tyler leads to a transgressive, violent initiation and results in his first taste of appreciation.

\subsection{A Great Ball of Doubt}

Though at first glance it would appear that a great ball of doubt is the exact opposite of a great root of faith, it means to be aware at all times of one's own lack of insight and to harbor within oneself a deep distrust of 'I' (Sōkō 1988, p. 28).

According to Sōkō, despite the seeming unshakeability of his resolve to subject himself to violence and even death for the sake of his religion, he came to discover his strength of will by being tested to persevere in face of his personal misery (Sōkō 1988, p. 26).

After showing Jack's exhilaration from breaking down his attachment to his 'good boy' identity in the first fight, Fincher shows Jack's resolve being tested in a series of short montages of fights with others, at the end of which Jack states: "After fighting, everything else in your life got the volume turned down ... You could deal with anything." ${ }^{23}$ In each new fight scene, Fincher uses specific film techniques to gradually increase the audience's identification with Jack and subjective engagement with the violence. For example, he places the camera closer to the action; incorporates fewer over-the-shoulder references; uses more POV shots; shows more blood in reaction shots; grows the crowd sizes; gives longer build-ups to the fights; highlights the vulnerability of the skin with high contrast lighting; moistens the sound effects of punches; increases the echo on the background crowd noise; and has punches land in frame rather than out of frame. By reducing the audience's ability to maintain emotional distance from the fighters through these techniques, Fincher tests the audience's

22 Time code 32:27 marks the start of the re-enactment scene.

23 39:12. 
own resolve to persevere, making it possible for them to identify with Jack's sense of accomplishment, when he finally declares: “Fight Club wasn't about winning or losing. It wasn't about words. The hysterical shouting was monotonous, like at a Pentecostal church. When the fight was over, nothing was solved, but nothing mattered. Afterwards, we all felt saved." ${ }^{24}$

Although the montage of fights makes clear that Jack gains some sense of Zen-like peace and salvation through fighting, he still does not harbor sufficient "distrust of ' $\mathrm{I}$ ', " is unaware of "his lack of insight," and has not been tested by truly miserable pain. To break Jack's arrogance and develop the "great ball of doubt" that he needs to progress, Tyler makes Jack face his own limitations by burning his hand with lye. To emphasize Jack's inability to face the fact of his own vulnerability in this scene, Fincher frames the action around a simple two-shot conversation across a table from one another. As the scene proceeds, Fincher's camera shows fewer over the shoulder POV shots, more direct POV shots without any reference, and moves in tighter-all in order to make the audience not only identify with Jack's intense pain but to feel it more viscerally. Fincher demonstrates Jack's flailing attempts to escape the pain by inserting cut-away shots to Jack's meditation landscape and penguin-guide, but then Fincher abruptly jump cuts back to the scene as Tyler calls him back to the present moment over and over to show Jack, and the audience performatively, that Jack's taste of salvation through fighting is immature. Once the harrowingly painful scene is finished and Jack is left with a scar on his hand, he and the audience will remain aware at all times of the Zen lesson that "ego" may claim salvation but there is always more to go on the path to enlightenment.

\subsection{Fierce Tenacity}

Fierce tenacity of purpose means to have the real courage to continue the practice, whatever the obstacles (Sōkō 1988, p. 28).

According to Sōkō, he himself developed real courage by carrying on without resistance in order to practice Zen humbly even at the cost of his life (Sōkō 1988, p. 27).

In the scene where Tyler overcomes a threat to the fight club by putting up no resistance to the gangster bashing his face in, Tyler teaches Jack by example what it means to have real courage in humbleness. ${ }^{25}$ In order to communicate this in the visual sub-text of the scene, Fincher shoots the first part of the scene from the low angle from Tyler's POV in his humble and vulnerable position, but reverses to a high angle from Tyler's POV in the end of the scene as Tyler finally overcomes the threats of the gangster by sacrificing himself with great pleasure and laughter. By accompanying these shots with the droning yet spiritually evocative non-diegetic sounds of a sitar-a well-worn cinematic trope for the wisdom and magic of the East-Fincher conveys to the audience Tyler's spiritually superior position in being beyond violence. To show that Tyler is teaching Jack, by example, to overcome mundane obstacles through joyful self-sacrifice rather than through aggression, Fincher's frame keeps Jack lurking in the background of many shots and cuts to him for reactions. When a gangster's gun is pulled and Jack is about to step in to help Tyler, Tyler waves Jack off-his hand filling the frame from Jack's POV-to communicate that he wishes to show Jack and the others the power of tenacious and deliberate self-sacrifice for a greater purpose. After Tyler is pummeled while laughing maniacally, Fincher creates a visceral reaction in the audience by cutting from Tyler's blood-covered face to a close-up reaction shot of an onlooking bystander vomiting into a trash can. To emphasize Tyler's spiritual victory, Fincher has the fight club members carry Tyler's injured body to a seat, which functions in the context like a religious throne, from which Tyler doles out religious advice in the form of a "homework assignment" for his disciples to go out and deliberately get themselves beaten up by a stranger. By glorifying the pugilistic violence in these ways, Fincher marks the moment that the fight club changes from a Zen-like path of personal discovery into a proselytizing religion where 
others are encouraged to adopt an even more violent theology based largely on Tyler's charismatic and courageous example.

As the film continues, Jack's root of faith, his great ball of doubt, and his tenacity of purpose are all tested by increasing challenges, some of which seem to get the better of him for a time until he finally shoots himself in the mouth to destroy the "I." When Jack strays from the path, Fincher's presentation of violence increasingly emphasizes its brutality, e.g., in the convenience store scene, where Tyler holds a gun to the clerk's head, Fincher places the clerk's crying face in the foreground of the wide-angle shot and emphasizes it with close-ups and subjective angles throughout the scene. Then, later, when Jack lets anger corrupt his fight club experience, Fincher emphasizes the grotesqueness of the violence. For example, in the scene where Jack destroys the face of the blond Pretty Boy (played by Jared Leto), Fincher uses out-of-sync reverberating, low-garbled tones dissociated from the action; exaggerated thuds and sound effects; and skewed cut-aways to wide angle extreme close-up shots of distorted, screaming, and cringing mouths agape and aghast. At the culminating point, Fincher uses tight shots of Jack's punches, from the victim's POV, landing right on the camera glass, so that spectators suddenly feel like they themselves are being punched in the face. In this way, Fincher makes the audience experience a type of reflexive awareness, in which there is a breakdown of the distinction between the "subject," with whom they were identified, and themselves as "object" of his punches. To mark this reflexive awareness as the turning point in Jack's spiritual sidetrack, Fincher ends the scene with a 180-degree camera tilt that stops in an upside down low-angle, long shot of Jack's departure, from the victim's disembodied POV.

However, the true purpose of the third mysterious gate is expressed in the final scene where Jack puts his life on the line and, shockingly, shoots himself in the mouth in order to destroy his "I," as a result of which he hopes to see the true nature of his own mind and break through to awakening. With this sequence, the audience comes to identify with Jack once again and understands his shooting himself while saying, "My eyes are wide open," as performatively "killing the buddha." Since Jack survives the shot to the brain - which magically eliminates the misfiring neuron that led him to his initial dissociative disorder of imagining the teacher to be separate and distinct from himself in the first place-he finally completely solves the subject-object dichotomy inherent in his own personal kōan and emerges in touch with himself as the real buddha.

\section{Conclusions}

Without discounting its many non-Buddhist influences or trying to suggest Fight Club is a "Buddhist film," this article has shown the way that watching Fight Club can be considered a revelatory experience when viewed from the perspective of the three mysterious gates that encapsulate Rinzai Zen pedagogy. For Whalen-Bridge, if a film does not have a Buddhist creator, subject, setting, or implication (Whalen-Bridge 2014, p. 55), it must be considered a "draftee." But this rubric does not account for the many levels on which Buddhists or non-Buddhists might read a film as "Buddhist," nor for the fact that they might very well disagree about whether or not a particular film is truly Buddhist or just a form of Buddhist malpractice. But setting aside any attempt to find the Buddhist-ness of a film within the film itself, and whether or not viewers interpret or experience Fight Club as I describe it from the perspective of film theory, hopefully my analysis will raise the level of the film's reception and, at the very least, open up a discussion going forward about the possible Buddhist ways of seeing the film and Fincher's choices in making it. Interestingly, apart from describing Fight Club in line with the Rinzai Zen path to enlightenment, Fincher said that he put much effort into making sure that the audience cannot possibly anticipate the final twist coming, but that he also set up the twist by planting clues from the beginning about the punchline that viewers would recognize and understand only in retrospect, e.g., his two-frame flashes of Tyler appearing over Jack's shoulder within different 
scenes. ${ }^{26}$ In this way, Fincher strongly suggests that Fight Club is, by design, not a film to be understood while watching it the first time. It is to be contemplated and decoded by repeatedly looking not only at the content but at the viewer's experience of the content in light of the final twist. Until one understands all the "enigmatic and often shocking spiritual expressions based on dialogical encounters between masters and disciples" (Heine and Wright 2000, p. 3; Hori 2000, p. 304) as trying to express the inexpressible, one will not see how the film aims to serve as a pedagogical tool for audiences to contemplate and develop insight into the illusory nature of the distinct identities to which all deluded beings are attached. Thus, in this way too, it is like a kōan.

Funding: This research received no external funding.

Conflicts of Interest: The author declares no conflict of interest.

\section{References}

Bourdieu, Pierre. 1993. Outline of a Sociological Theory of Art Perception. In The Field of Cultural Production: Essays on Art and Literature. Edited and Introduced by Randal Johnson. New York: Columbia University Press, ISBN 0-231-08286-X. First published in 1968. International Social Science Journal 20 (Winter): 589-612. Available online: http:/ / web.mit.edu/allanmc/www /bourdieu3.pdf (accessed on 1 June 2018).

Bourdieu, Pierre. 1995. Outline of a Theory of Practice, 11th reprint. Translated by Richard Nice. Cambridge: Cambridge University Press. First published 1977. ISBN 0-521-29164-X.

Brant, Jonathan. 2012. Paul Tillich and the Possibility of Revelation through Film: A Theoretical Account Grounded by Empirical Research into the Experiences of Filmgoers. Oxford: Oxford University Press. ISBN 978-0-19-963934-2.

Braudy, Leo, and Marshall Cohen. 2004. Film Theory and Criticism: Introductory Readings, 6th ed. New York: Oxford University Press.

Buswell, Robert E., Jr. 1986. Chinul's systematization of Chinese meditative techniques in Korean sŏn buddhism. In Traditions of Meditation in Chinese Buddhism. Edited by Peter N. Gregory. Honolulu: University of Hawaii Press, pp. 199-242. ISBN 0-8248-1088-0.

Ch'en, Kenneth K. S. 1973. Buddhism in China: A Historical Survey, 2nd ed. Princeton: Princeton University Press. ISBN 0-691-00015-8.

Cho, Francisco. 2017. Seeing Like the Buddha: Enlightenment through Film. Albany: State University of New York Press. ISBN 9781438464398.

Dorsky, Nathaniel. 2007. The Religion and Film Reader. Edited by Jolyon P. Mitchell and S. Brent Plate. New York: Routledge, pp. 407-16.

Elsaesser, Thomas, and Malte Hagener. 2010. Film Theory: An Introduction Through the Senses. New York: Routledge. ISBN 0-415-80100-X.

Faure, Bernard. 1994. The Rhetoric of Immediacy: A Cultural Critique of Chan/Zen Buddhism, 1st reprint. Princeton: Princeton University Press. ISBN 0-691-02963-6.

Fielding, Julien R. 2008. Discovering World Religions at 24 Frames per Second. Plymouth: Scarecrow Press. ISBN 10 0-8108-5996-3.

Foster, Nelson, and Jack Shoemaker. 1996. The Roaring Stream: A New Zen Reader. Hopewell: The Ecco Press. ISBN 0-88001-511-6.

Green, Ronald S. 2014. Buddhism Goes to the Movies: An Introduction to Buddhist Thought and Practice, 2nd ed. New York: Routledge. ISBN 978-0-415-84148-1.

Heine, Steven, and Dale S. Wright. 2000. Introduction: Kōan tradition-Self-narrative and contemporary perspectives. In The Kōan: Texts and Contexts in Zen Buddhism. Edited by Steven Heine and Dale S. Wright. Oxford: Oxford University Press, pp. 3-15. ISBN 13-978-0-19-511749-3.

26 Cf. (Smith [1999] 2014, p. 62)) "You can't [see the twist coming] ... We spent tons of money to get two different people to make sure that you wouldn't know ... What people want from the movies is to be able to say, I knew it and it's not my fault." 
Hori, G. Victor Sōgen. 2000. Kōan and Kenshō in Rinzai Zen Curriculum. In The Kōan: Texts and Contexts in Zen Buddhism. Edited by Steven Heine and Dale S. Wright. Oxford: Oxford University Press, pp. 280-315. ISBN 13-978-0-19-511749-3.

Jenkins, Richard. 1992. Pierre Bourdieu. London: Routledge.

Jerryson, Michael K. 2018. If You Meet the Buddha on the Road: Buddhism, Politics, and Violence. Oxford: Oxford University Press.

Jerryson, Michael K., and Mark Juergensmeyer. 2010. Buddhist Warfare. Edited by Michael K. Jerryson and Mark Juergensmeyer. Oxford: Oxford University Press. ISBN 978-0-19-539483-2.

Kapleau, Philip. 1988. The private encounter with the master. In Zen: Tradition and Transition. Edited by Kenneth Kraft. New York: Grove Press, pp. 44-69. ISBN 0-8021-3162-X.

Kraft, Kenneth. 1988. Recent developments in North American Zen. In Zen: Tradition and Transition. Edited by Kenneth Kraft. New York: Grove Press, pp. 178-98. ISBN 0-8021-3162-X.

Mohr, Michel. 2000. Emerging from Nonduality: Kōan Practice in the Rinzai Tradition since Hakuin. In The Kōan: Texts and Contexts in Zen Buddhism. Edited by Steven Heine and Dale S. Wright. Oxford: Oxford University Press, pp. 244-79. ISBN 13-978-0-19-511749-3.

Olson, Carl. 2005. The No-Narrative of Seated Meditation: Zen. In The Different Paths of Buddhism: A Narrative-Historical Introduction. New Brunswick: Rutgers University Press. ISBN 0-8135-3561-1.

Palahniuk, Chuck. 1996. Fight Club. New York: W.W. Norton \& Company. ISBN 0-393-31734-5.

Park, Jin Y. 2008. Buddhism and Postmordernity: Zen, Huayan, and the Possibility of Buddhist Postmodern Ethics. Plymouth: Lexington Books. ISBN 978-0-7391-1824-5.

Reed, Charley. 2007. Fight Club: An Exploration of Buddhism. Journal of Religion E Film 11. Available online: http:/ / digitalcommons.unomaha.edu/jrf/vol11/iss2/5 (accessed on 1 June 2018).

Satō, Kemmyō Taira. 2008. D.T. Suzuki and the Question of War. The Eastern Buddhist 39: 61-120.

Schlütter, Morten. 2000. "Before the Empty Eon" versus "A Dog Has No Buddha-Nature": Kung-an Use in the Ts'ao-tung Tradition and Ta-hui's Kung-an Introspection Ch'an. In The Kōan: Texts and Contexts in Zen Buddhism. Edited by Steven Heine and Dale S. Wright. Oxford: Oxford University Press, pp. 168-99. ISBN 13-978-0-19-511749-3.

Schneller, Johanna. 1999. Brad Pitt \& Edward Norton: Two Heavy Hitters Put Their Muscle Behind the Controversial Fight Club. Premiere: The Movie Magazine, August.

Sōkō, Morinaga. 1988. My struggle to become a Zen Monk. In Zen: Tradition and Transition. Edited by Kenneth Kraft. New York: Grove Press, pp. 178-98. ISBN 0-8021-3162-X.

Smith, Gavin. 2014. Inside Out. In David Fincher: Interviews. Edited by Laurence F. Knapp. Jackson: University Press of Mississippi, ISBN 978-1-62846-036-0. First published in 1999. Film Comment Magazine, Sept./Oct., 35/5. pp. 58-68. Available online: http:/ / cinetropolis.net/david-fincher-1999-film-comment-interview-onfight-club / (accessed on 1 June 2018).

Suzuki, Daisetz Teitaro. 1960. The Ten oxherding pictures. In Manual of Zen Buddhism. Translated by Daisetz Teitaro Suzuki. New York: Grove Press, pp. 150-71.

Van Der Braak, André. 2011. Nietzsche and Zen: Self-Overcoming without a Self. Plymouth: Lexington Books.

Verchery, Lina. 2018. Review of Francisca Cho's. In Seeing Like the Buddha: Enlightenment through Film. Albany: State University of New York Press. Available online: http:/ / www.h-net.org/reviews/showpdf.php?id=51178 (accessed on 1 June 2018).

Victoria, Brian Daizen. 2006. Zen at War, 2nd ed. Lanham: Rowman \& Littlefield Publishers. Whalen-Bridge, John. 2014. What is a 'Buddhist Film?'. Contemporary Buddhism 15: 44-80. [CrossRef]

(c) 2018 by the author. Licensee MDPI, Basel, Switzerland. This article is an open access article distributed under the terms and conditions of the Creative Commons Attribution (CC BY) license (http:// creativecommons.org/licenses/by/4.0/). 